\title{
Introduction: British Queer History
}

\author{
Brian Lewis
}

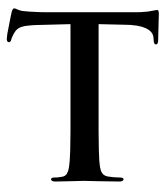

he Journal of British Studies (JBS) came to sex relatively recently. Nancy Anderson penned an early piece in 1982 on Victorian incest anxiety, but it was not until Alan Bray wrote a review essay in the April 1993 issue, critiquing a number of recent contributions to the history of sexuality and of sexual diversity, that the journal began to mine this rich seam more systematically. ${ }^{1}$ Since then, as more and more scholars have taken the "sexual turn," the $J B S$ has kept pace. Notable contributions have included Iain McCalman on riot and sexuality in the genesis of Burke's Reflections, David Cressy on gender trouble and cross-dressing in early modern England, Pamela Cox on sexual health after the Contagious Diseases Acts, Faramerz Dabhoiwala on sex and societies for moral reform in the eighteenth century, and Adrian Bingham on social surveys and sexual culture in the 1940s and 1950s. ${ }^{2}$ The more specifically "queer" articles have been just as heavyweight: Martha Vicinus on lesbian perversity and Victorian marriage in the 1864 Codrington divorce trial; Brian Cowan on the Earl of Shaftesbury and libertinism; Matt Houlbrook on homosexuality, Britishness, and masculinity in the Guards; Rebecca Jennings on lesbians and psychiatry in the postwar decades; and Joseph Bristow's overview of the "new British gay history." 3

Brian Lewis is an associate professor in the Department of History and Classical Studies at McGill University. $\mathrm{He}$ is also an associate editor of the Journal of British Studies.

${ }^{1}$ Nancy F. Anderson, “The 'Marriage with a Deceased Wife's Sister Bill' Controversy: Incest Anxiety and the Defense of Family Purity in Victorian England," Journal of British Studies 21, no. 2 (Spring 1982): 67-86; Alan Bray, "Historians and Sexuality," Journal of British Studies 32, no. 2 (April 1993): 189-94.

${ }^{2}$ Iain McCalman, "Mad Lord George and Madame La Motte: Riot and Sexuality in the Genesis of Burke's Reflections on the Revolution in France," Journal of British Studies 35, no. 3 (July 1996): 34367; David Cressy, "Gender Trouble and Cross-Dressing in Early Modern England," Journal of British Studies 35, no. 4 (October 1996): 438-65; Pamela Cox, "Compulsion, Voluntarism, and Venereal Disease: Governing Sexual Health in England after the Contagious Diseases Acts," Journal of British Studies 46, no. 1 (January 2007): 91-115; Faramerz Dabhoiwala, "Sex and Societies for Moral Reform, 1688-1800," Journal of British Studies 46, no. 2 (April 2007): 290-319; Adrian Bingham, "The 'KBomb': Social Surveys, the Popular Press, and British Sexual Culture in the 1940s and 1950s," Journal of British Studies 50, no. 1 (January 2011): 156-79.

${ }^{3}$ Martha Vicinus, "Lesbian Perversity and Victorian Marriage: The 1864 Codrington Divorce Trial," Journal of British Studies 36, no. 1 (January 1997): 70-98; Brian Cowan, "Reasonable Ecstasies: Shaftesbury and the Languages of Libertinism," Journal of British Studies 37, no. 2 (April 1998): 11138; Matt Houlbrook, "Soldier Heroes and Rent Boys: Homosex, Masculinities, and Britishness in the Brigade of Guards, circa 1900-1960," Journal of British Studies 42, no. 3 (July 2003): 351-88; Rebecca Jennings, “The most uninhibited party they'd ever been to': The Postwar Encounter between Psychiatry 
The current issue of the JBS continues this trend of publishing innovative work on the history of sexual diversity. I am grateful to Brian Cowan and Elizabeth Elbourne for giving me the opportunity to be guest editor. Some of the articles were first tried out at a conference at McGill University in October 2010, others were the result of a call for submissions, and all went through the usual process of double-blind peer review. The intention is to bring together some of the most interesting, diverse, and challenging new work in the flourishing subdiscipline of British Queer History. "Queer" is, of course, a notoriously slippery concept. The authors of the following articles highlight its multiple usages: queer as a widely used term of self-description but also of stigmatization that was abandoned postStonewall in favor of "gay"; queer as "peculiar"-nonnormative and unusual; queer as a reclaimed signifier of militancy adopted by grassroots radical activists in the late 1980s; queer as a capacious container for all the fragments of the lesbian, gay, bisexual, and transgendered "community"; and queer as the new theoretical language taking shape in the academy circa 1990, dedicated to disrupting sexual identities and hetero/homo binaries.

In his authoritative overview, "Queer(y)ing the 'Modern Homosexual," Jeffrey Weeks opens the collection of essays by reflecting on the transformation of the field since his own pioneering work in the 1970s on gay and lesbian history in Britain. He revisits the politically charged attempt to recover a usable past by the first wave of gay and lesbian historians and the origins of the social constructionist perspective, with its critical insight that same-sex activities can only be understood in a historical and cultural context. He gives a measured defense of his early work's emphasis on the late nineteenth century as a key moment in the "making of the modern homosexual." In underlining the point that the new queer history built on the foundational work of the 1970s, he suggests that the alleged epistemological rupture between the two has been exaggerated. In closing, he contends that, however much the past may be a foreign country, there are startling flashes of recognition between ourselves and the queer lives, loves, and desires of our ancestors.

Michael B. Young's article, "James VI and I: Time for a Reconsideration?" also engages with these flashes of recognition. His focus on James, long claimed as one of "the great queers of history," reassesses the evidence for the king's pederastic relations with a succession of favorites. Whereas earlier generations of historians sought to explain away or ignore the strong signs that James may have been a sodomite, Young relates how a broad consensus emerged among historians in the 1980s and 1990s that James did, in fact, engage in sexual acts with youths or young men. And yet, more recently, a number of prominent scholars have backed away from this affirmation, becoming much more equivocal about their assessments of the king's sexual practices. Young detects the perverse impact of queer history in explaining this "regression." Its emphasis on alterity, on the disruption of categories, and on the lack of continuity among pederasty, sodomy, and modern homosexuality has encouraged historians to question what they thought they had

and the British Lesbian, 1945-1971," Journal of British Studies 47, no. 4 (October 2008): 883-904; Joseph Bristow, "Remapping the Sites of Modern Gay History: Legal Reform, Medico-Legal Thought, Homosexual Scandal, Erotic Geography," Journal of British Studies 46, no. 1 (January 2007): 11642 . 
detected in the surviving evidence. Young robustly restates the case for a recognizable James who had sex with the men he loved.

If what we thought we knew about James VI and I is heavily contested, Farid Azfar's article, "Genealogy of an Execution: The Sodomite, the Bishop, and the Anomaly of 1726," seeks to disrupt our certainties about another staple of British queer history: the eighteenth-century molly house and the persecution of the mollies. Azfar challenges the orthodox interpretation that the execution of three men in the trials of 1726 constituted an alignment of cultural intolerance and state power in a coordinated pogrom against the effeminate other. In making use of clerical correspondence, previously overlooked by historians of sexuality, he instead marshals a strong case for interpreting these events in terms of contingency and anomaly. In arguing that the men were caught in the crossfire of leading figures in church and state with competing social and political agendas, Azfar makes an eloquent plea for historians to balance the diachronic against the synchronic and to recognize - and appreciate the political usefulness of-incoherence.

A third staple of British queer history is the Cleveland Street Scandal of 1889, the revelation that a number of higher-class males had bought the sexual services of Post Office messenger boys in a London brothel. Katie Hindmarch-Watson, using records in the British Postal Heritage Museum and Archive also previously neglected by historians of sexuality, unearths an earlier episode linking the telegraph boys to sex work. In "Male Prostitution and the London GPO: Telegraph Boys' 'Immorality' from Nationalization to the Cleveland Street Scandal," her richly detailed assessment of an internal investigation of 1877, she deliberately sidesteps the question of sexual subjectivity since nothing is known about how the boys perceived their sexual selves. Instead she grapples with another Foucauldian insight-liberal governmentality - and the connections among the state, communications technology, and sex in the production of the liberal citizen. The telegraph boys, she argues, occupied a liminal position: they were indispensable for the functioning of the well-ordered, efficiently communicating city while at the same time becoming deeply enmeshed in London's sexual markets, perpetuating the unruly metropolis of pederastic vice.

If the first half of this volume challenges us to reevaluate familiar episodes and perspectives in queer history, the second half moves us into less charted territory. Matt Cook's focus on queer domestic space is far removed from sexual expression, public scandal, or newly emerging homosexual identities. In "Domestic Passions: Unpacking the Homes of Charles Shannon and Charles Ricketts," his subtle analysis of the lives, art, collecting, and friendship of this artist couple, who may or may not have had sex with each other and with other men, Cook makes the case for a more expansive, more nuanced, and more complex sense of queerness. In exploring and opening up their intimate space, he argues for not only the multiplicity of possible queer identifications in the late nineteenth and early twentieth centuries but also the ways in which it is possible to recover and historicize queer identification with domesticity. The postwar emphasis on companionate and private queer love, it seems, had important precursors.

Just as Cook discovers queerness in the turn-of-the-century home, usually associated with opposite-sex, conjugal, and reproductive norms, Laura Doan's article, "Sex Education and the Great War Soldier: A Queer Analysis of the Practice of 'Hetero' Sex," takes us a step further from the comfort zone of queer history, 
challenging us to view a wholly heterosexual artifact through queer eyes. Her deployment of "queerness as method" moves beyond an identitarian framework, the recovery of same-sex behavior and desires, toward the disruption of stable categories and of the hetero-homo binary. This, of course, has been part of the queer theory project for the last couple of decades, but, Doan maintains, too often scholars have measured a queer fluidity against a stable, unchanging heterosexuality. Her queer analysis of a World War I sex education film, which was designed to highlight appropriate heterosexual conduct and counteract venereal disease, seeks to interrogate the production of heteronormativity, to disturb its universal, transhistorical status. She makes a powerful case for the queering of heterosexuality just as much as for homosexuality.

Lisa Z. Sigel's take on queerness propels us in yet another direction, toward fetishism. The focus in her article, "Fashioning Fetishism from the Pages of London Life," is on both "queer" meaning bent, odd, or kinky and "queer" in the sense of desires that overflowed neat sexological categories. Her reading of the magazine London Life during the interwar years explores and contextualizes a variety of "queer and kinky pleasures" (664). She highlights three of these fetishes: the girl boxer or wrestler, whose exploits provided titillation while subverting gendered norms; the tight-laced girl, whose corseted figure spoke to an eroticized nostalgia for the potential of pleasure and pain, renunciation and control; and the female amputee, whose fetishization spoke to the erotic possibilities of trauma and loss. In the correspondence pages of this mainstream publication, untroubled by censors and morality campaigners, letter writers scripted, indulged, and shared their sexual selves to a surprising extent.

In the final article, "The Homosexual as a Social Being in Britain, 1945-1968," Chris Waters's concern is with how and why "experts" reconceptualized the male homosexual in the postwar period, transforming him from a biological, psychosexual, and often pathological problem into a social being. In meticulous detail, Waters traces how the homosexual became seen as part of a minority pursuing a particular way of life- a social problem amenable to social solutions and forms of management. His contention is that scholars have paid so much attention to the radical liberationist paradigm shift of the late 1960s, and its denigration of most of what went before, that they have overlooked the crucial work of earlier postwar writers who carved out a space for the study of homosexuality as a social phenomenon. Through his investigation of the context in which historians and sexologists like Jeffrey Weeks began their pioneering work, he brings us full circle. 